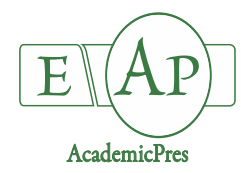

Farahani H et al. (2020)
Notulae Botanicae Horti Agrobotanici Cluj-Napoca 48(3):1560-1572
DOI: $10.15835 /$ nbha48311808
Research Article

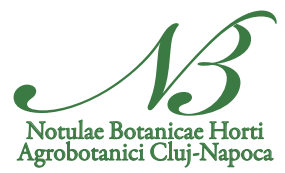

\title{
Physiological and biochemical responses of Damask rose (Rosa damascena Miller) to potassium silicate application under water deficit stress
}

\author{
Hossein FARAHANI ${ }^{1}$, Nour Ali SAJEDI ${ }^{2 *}$, Hamid MADANI ${ }^{2}$, \\ Mehdi CHANGIZI ${ }^{2}$, Mohammad R. NAEINI ${ }^{3}$
}

\author{
${ }^{1}$ Department of Horticultural Science, Arak Branch, Islamic Azad University, Arak, Iran; Farahani49@yahoo.com \\ ${ }^{2}$ Department of Agronomy and Plant Breeding, Arak Branch, Islamic Azad University, Arak, Iran; n-sajedi@iau-arak.ac.ir \\ (*corresponding author);h-madani@iau-arak.ac.ir; m-changizi@iau-arak.ac.ir \\ ${ }^{3}$ Qom Agricultural and Natural Resources Research and Education Center Agricultural Research, Horticulture Crops Research \\ Department, Education and Extension Organization (AREEO),Tehran, Iran; naeini2000@yahoo.com
}

\begin{abstract}
In this field experiment, the effect of potassium silicate (PS) on the physiological and biochemical responses of Damask rose was investigated under the water deficit stress. The treatments were four levels of irrigation water application including 100, 75, 50 and 25\% plant water requirement (PWR) and potassium silicate at three rates ( 0 , i.e., just pure water, 0.2 and $0.4 \%$ ), once (in spring or summer) or twice (once in spring and once in summer) during the plant growth. The results showed that with irrigation of $75 \%$ of plant water requirement significantly reduced the concentration of chlorophyll $a(\mathrm{Chl} a, 170 \%)$, chlorophyll $b(\mathrm{Chl} b$, $163 \%$ ) and carotenoids (91\%), the leaf relative water content (RWC, 14.8\%) and the total flower yield (20\%) as compared to control. The elevated malondialdehyde (MDA) content and ion leakage, as two indicators of oxidative damage, were observed in the plants subjected to the water deficit stress. In response to oxidative stress induced by water deficit stress, the leaf catalase (CAT, 59.5\%) activity and concentration of proline (64.8\%) as compared to control increased. The foliar-applied $\mathrm{Si}$ at two rates of 0.2 and $0.4 \%$ in spring and summer resulted in a higher concentration of $\mathrm{Chl} a(57.3 \%$ and $61.7 \%)$, Chl $b(31 \%$ and $24.6 \%)$ and carotenoid content as compared to control, respectively. The increased concentration of proline and higher activity of CAT in the plants supplied with Si led to the higher leaf RWC and less intensity of oxidative damage, namely ion leakage and MDA content. According to the results, with the potassium silicate spraying in 0.2 or $0.4 \%$ both in spring and summer at the irrigation level equal to $50 \%$ of the PWR, the optimum flower yield was achieved.
\end{abstract}

Keywords: antioxidant; plant pigments; potassium silicate; Rosa damascena Miller; water deficit stress

Abbreviations: CAT: Catalase; MDA: Malondialdehyde; PS: Potassium silicate; PWR: Plant water requirement; RWC: Relative water content; SOD: Superoxide dismutase

Received: 09 Feb 2020. Received in revised form: 24 Aug 2020. Accepted: 07 Sep 2020. Published online: 18 Sep 2020. 


\section{Introduction}

The flower of Damask rose (Rosa damascena Miller.) belongs to the Rosaceae family. Damask rose flower has been greatly cultivated in Iran during the recent years mainly due to the adaptation of this plant to different climate conditions, low cost of production, and considerable profitability expected from the production of this plant. The essential oil of Damask rose flower is one of the most valuable materials used in the perfume industry (Baydar and Baydar, 2004). The small industries associated with the production of Damask rose play an important role in economy and job creation in the rural areas (Kodori and TabaeiAghdaei, 2007).

Plants are often subjected to the environmental stresses such as salinity, drought, high and low temperatures, which greatly reduce the growth and yield (Ahmad and Prasad, 2012). Water deficit is an important environmental stress limiting the production of crops in the arid and semi-arid regions of the world including Iran (Amin et al., 2015). Plants have evolved several physiological and biochemical mechanisms to cope with the biotic and abiotic stresses (González-Orenga et al., 2020). Plants use enzymatic and nonenzymatic antioxidant mechanisms to alleviate the oxidative stress induced by the excess accumulation of reactive oxygen species (ROS) (Hasanuzzaman et al., 2014). It has been reported that the activity of superoxide dismutase and the content of malondialdehyde in maize increased under the water deficit stress, but the grain yield was reduced (Sajedi et al., 2011).

Silicon $(\mathrm{Si})$ is a beneficial nutrient element whose positive effect on the plant tolerance to the environmental stresses has widely been reported (Torabi et al., 2013; Gengmao et al., 2015). It has been reported that the application of silicon enhances the plant tolerance to stress salinity, drought, thermal, and heavy metal etc, through the regulation of free oxygen radicals, decrease of ion leakage, reduction of malondialdehyde content, and decline in sodium adsorption (Kim et al., 2017). Scavenging free radicals is one of the most important defense mechanisms in plants for the tolerance to stress conditions (Baxter et al., 2014). A possible mechanism by which $\mathrm{Si}$ enhances plant tolerance to biotic and abiotic stresses is the increase in the activity of antioxidant enzymes and the content of osmolytes (Liang et al., 2007). Silicon improves the plant ability to scavenge free oxygen radicals via increasing the activity of antioxidant enzymes (Tripathi et al., 2017). The application of $\mathrm{Si}$ in the form of potassium silicate improved the activity of superoxide dismutase and catalase in honeysuckle medicinal plant under the salinity conditions (Gengmao et al., 2015). It has been reported that the application of silicon enhances the $\mathrm{Chl} a$ and $\mathrm{Chl} b$ contents in maize cultivars compared to the $\mathrm{NaCl}$-treated plants and found that the application of silicon can moderate the salinity stress without decreasing the growth attributes in maize (Reza et al., 2019). Pereira et al. (2013) reported that the use of silicon in pepper plants subjected to the water deficit stress resulted in the higher proline synthesis.

Despite extensive reports on the positive effect of Si on the tolerance to the stress in several plants, little information is available on the role of $S i$ in Damask rose under the water deficit conditions. Therefore, this field study aimed to investigate the physiological and biochemical responses and flower yield of Damask rose in the foliar-applied Si under water deficit conditions.

\section{Materials and Methods}

\section{Experimental procedure}

This field experiment was conducted in 2018 as split plot based on the randomized complete block design with three replications at Karimah Zaer research station located in Qom province, Iran. The annual rainfall of the area is $155 \mathrm{~mm}$ and the average annual temperature is $24^{\circ} \mathrm{C}$. Table 1 shows the selected physicochemical characteristics of the soil. 
Table 1. Physical and chemical soil properties of the experimental site

\begin{tabular}{|c|c|c|c|c|c|c|c|c|c|c|}
\hline $\begin{array}{c}\text { Soil } \\
\text { depth } \\
(\mathrm{cm})\end{array}$ & $\begin{array}{c}\mathrm{EC} \\
\left(\mathrm{dS} \mathrm{m}^{-1}\right)\end{array}$ & $\mathrm{pH}$ & $\begin{array}{c}\text { Absorption } \\
\text { available } \\
\mathrm{P} \\
\left(\mathrm{mg} \mathrm{kg}^{-1}\right)\end{array}$ & $\begin{array}{c}\text { Absorption } \\
\text { available } \\
\mathrm{K}\end{array}$ & $\begin{array}{c}\mathrm{N} \\
\left(\mathrm{mg} \mathrm{kg}^{-1}\right)\end{array}$ & $\begin{array}{c}\text { Absorption } \\
\text { available } \\
\mathrm{Si} \\
\left(\mathrm{mg} \mathrm{kg}^{-1}\right)\end{array}$ & $\begin{array}{c}\text { OC } \\
(\%)\end{array}$ & $\begin{array}{c}\text { Sand } \\
(\%)\end{array}$ & $\begin{array}{c}\text { Silt } \\
(\%)\end{array}$ & $\begin{array}{c}\text { Clay } \\
(\%)\end{array}$ \\
\hline $0-60$ & 1.2 & 7.9 & 17 & 225 & 0.07 & 0.07 & 0.71 & 36 & 44 & 20 \\
\hline
\end{tabular}

EC: Electrical conductivity, OC: organic carbon

The studied factors included the water deficit stress at four levels of 100 (well-watered), 75, 50 and 25\% of plant water requirement. These levels of irrigation water were used throughout the growing season. Potassium silicate was used at three rates (0, i.e., just pure water application, 0.2 and $0.4 \%$ of potassium silicate solution) once (in spring or summer) or twice (once in spring and once in summer) during the plant growth. Each plot consisted of one row with a distance of 2 meters between the shrubs and a distance of 4 meters between the replications. In each treatment, five shrubs were considered. The study was conducted on 4-yearold flower garden shrubs. The irrigation was performed using the drip irrigation system. The evapotranspiration in the area was calculated through the report No. 56 of FAO and Cropwat software (Bidabadi et al., 2013; Barzegari and Malekinezhad, 2016). The evapotranspiration of Damask rose was calculated according to the following formula (Sharifi Ashoorabadi et al., 2015).

$\mathrm{ETc}=\mathrm{ETo} \times \mathrm{Kc}$

Where: (ETo) evapotranspiration of reference plant (alfalfa) based on standard FAO method; (Kc) Damask rose coefficient at each growth stage; (ETc) evapotranspiration of Damask rose in $\mathrm{mm} /$ day.

After calculating the ETc values with applying plant coefficients in each growth period and summing the daily evapotranspiration of plant growth period (230 days) based on the meteorological data, soil and plant characteristics and planting intervals counting water requirement for leaching and net water and gross water requirement, the water requirement of Rosa damascena was determined to be 4500 cubic meters per hectare according to Cropwat software. According to the above calculations, the irrigation was done for 4, 3, 2 and 1 hours once a week in treatments of 100,75, 50 and 25\% PWR, respectively. The irrigation was done from ice water in winter towards the end of growth period using the water counter. The volume of water used for treatments of 100, 75, 50 and 25\% PWR was 4500, 3375, 2250 and $1125 \mathrm{~m}^{3}$, respectively. Potassium silicate was prepared from Biniz Tajhiz Company which contained $20 \% \mathrm{SiO}_{2}$ and $10 \% \mathrm{~K}_{2} \mathrm{O}_{5}$. The foliar application was carried out in the beginning of April after the leaves were fully expanded and in the end of the flowering stage in the beginning of July. The foliar application of potassium silicate was performed in two stages at a 15day interval on the aerial parts of the shrubs. In order to measure the physiological and biochemical traits, the samples were collected at fully expanded young leaves on July 25, 2018.

\section{Measurement of plant pigments}

For the extraction and measurement of plant pigments, one gram of leaves was ground with $5 \mathrm{~mL}$ of $80 \%$ acetone in porcelain mortar and centrifuged at $8000 \mathrm{rpm}$ for $10 \mathrm{~min}$. The light absorption rate by the extract was measured at $645,663,470,480$, and $510 \mathrm{~nm}$ wavelengths using the spectrophotometer (Varian 300 Scans, USA). The concentrations of plant pigments were calculated in terms of $\mathrm{mg} / \mathrm{g}$ of fresh weight (Arnon, 1949; Dhopte and Manuel, 2002).

\section{Determination of cell ion leakage}

Ion leakage was measured according to Lutts et al. (1996). For this purpose, the discs of leaves were prepared. The discs were washed with distilled water and placed in a tube. They were added $20 \mathrm{~mL}$ of distilled water and placed on a rotary shaker at $25^{\circ} \mathrm{C}$ for $24 \mathrm{~h}$. Electrical conductivity (EC) was measured using an EC meter $\left(\mathrm{EC}_{1}\right)$. In order to measure the total electrolyte leakage, the specimens were placed in an autoclave at 120 
${ }^{\circ} \mathrm{C}$ for $20 \mathrm{~min}$. The $\mathrm{EC}$ was measured again $\left(\mathrm{EC}_{2}\right)$. Ionic leakage (\%) was calculated based on the following equation:

$$
\mathrm{EL}(\%)=\frac{\mathrm{EC} 1}{\mathrm{EC} 2} \times 100
$$

Where $\mathrm{EC}_{1}$ is the electrical conductivity of the solution 24 hours after the samples are placed in distilled water and $\mathrm{EC}_{2}$ is the second reading 20 minutes after the autoclave.

\section{Relative water content of leaves}

A number of fully developed leaves were taken from each experimental plot and immediately transferred to the laboratory and weighted. Five discs with a diameter of $1 \mathrm{~cm}$ were prepared from each leaf and weighted (fresh weight). Then, the discs were submerged in distilled water for $24 \mathrm{~h}$ at $4{ }^{\circ} \mathrm{C}$, the distilled water was discharged and the excess moisture was removed using the filter paper. The discs were weighted (saturated weight) and dried inside the oven at $65^{\circ} \mathrm{C}$ for $72 \mathrm{~h}$. The RWC of leaves was calculated from the following equation (Dhopte and Manuel, 2002).

$$
\text { Relative water content }(\%)=\frac{\text { fresh weight }- \text { dry weight }}{\text { saturated weight }- \text { dry weight }} \times 100
$$

\section{Proline content}

To measure free proline, $0.5 \mathrm{~g}$ of intact leaves were ground in the porcelain mortar. Then, $10 \mathrm{~mL}$ of $3 \%$ sulfosalicylic acid was added and the contents of the mortar were stirred. Then, the contents of the mortar were filtered and $2 \mathrm{~mL}$ of this solution was added to $2 \mathrm{~mL}$ of ninhydrin acid $+2 \mathrm{~mL}$ of acetic acid in a test tube and the tube ends were closed. Then, the test tubes were placed in a boiling bath at $100{ }^{\circ} \mathrm{C}$ for one hour. Immediately afterwards, the tubes were placed inside the ice and $4 \mathrm{~mL}$ of toluene was added to each tube and stirred for $20 \mathrm{sec}$. The temperature was then allowed to reach the laboratory temperature. Then, the soluble colored part in toluene was isolated and its concentration was read by a spectrophotometer at the wavelength of $520 \mathrm{~nm}$ (Bates et al., 1973).

\section{Antioxidant enzyme assay}

The Catalase activity was measured using the method described by Siminis et al. (1994) at $25^{\circ} \mathrm{C}$ with a spectrophotometer. At first, $150 \mathrm{mg}$ of ground leaf samples were mixed with $1.5 \mathrm{~mL}$ of extract buffer and centrifuged at $13000 \mathrm{rpm}$ for $20 \mathrm{~min}$. Potassium phosphate buffer and hydrogen peroxide were then added to the solution. The samples were read at time steps of $0,20,40$, and 60 seconds with a spectrophotometer at a wavelength of $240 \mathrm{~nm}$.

To measure the activity of SOD, $150 \mathrm{mg}$ of ground fresh leaf sample was mixed with $1.5 \mathrm{~mL}$ of buffer. The solution was centrifuged for $20 \mathrm{~min}$ at $1300 \mathrm{rpm}$ and then the calibration was performed with the control solution containing $2 \mu \mathrm{M}$ riboflavin, $134.03 \mathrm{mM}$ betanin, $2.4 \mathrm{mM}$ nitro yellow tetrazolium, $5.372 \mathrm{mM}$ EDTA, and $50 \mathrm{mM}$ potassium phosphate buffer. Then, using the spectrophotometer at a wavelength of $560 \mathrm{~nm}$, it was read at $25^{\circ} \mathrm{C}$ in a lightbox at four-time steps of $0,4,8$ and 12 min after applying 40 watts of fluorescent light (Giannopolitis and Ries, 1977).

\section{Malondialdehyde content}

To measure the MDA content, $0.5 \mathrm{~g}$ of fresh leaf samples were ground in liquid nitrogen in the mortar for $1 \mathrm{~min}$. Then, the powdered leaves were poured into the test tube and mixed with $5 \mathrm{~mL}$ of potassium phosphate buffer $(\mathrm{pH}=7)$. The sample was centrifuged at $1400 \mathrm{rpm}$ for $30 \mathrm{~min}$ and then added to $1 \mathrm{~mL}$ of the solution after the centrifuge, $1 \mathrm{~mL}$ of thiobarbituric acid containing trichloroacetic acid (20\%). The solution was heated in a hot water bath at $95^{\circ} \mathrm{C}$ for $30 \mathrm{~min}$. In order to stop the reaction, the solution container was heated and quickly transferred to the ice bath and allowed to remain in the bath for $30 \mathrm{~min}$, and then it 
was centrifuged at 10,000 rpm for $10 \mathrm{~min}$. The absorption of the solution was measured by UV-VIS spectrophotometer at two wavelengths of $532 \mathrm{~nm}$ and $600 \mathrm{~nm}$ (Aravind and Prasad, 2005).

\section{Statistical analysis}

This experiment was conducted as the split plot based on the randomized complete block design with three replications. The statistical analysis of data was performed using SAS software and the comparison of the means was made using the Duncan's multiple range test (DMRT) at the $5 \%$ probability level.

\section{Results}

The results showed that the effect of irrigation treatments on the traits of chlorophyll $a$, chlorophyll $b$, total chlorophyll, carotenoids and RWC content, leaf proline, and activity of CAT were significant at the 1\% probability level, and the effect on the traits of ion leakage, activity of SOD, and flower yield were significant at the $5 \%$ probability level. The effect of foliar application of Si on the traits of carotenoid content was significant at the $5 \%$ probability level, and the effect on the traits of chlorophyll $a$, chlorophyll $b$, total chlorophyll, RWC content, ion leakage, leaf proline, concentration of malondialdehyde, activity of CAT, and SOD was significant at the $1 \%$ probability level. The interaction between potassium silicate spraying and irrigation treatments affecting the carotenoid content, ion leakage, leaf proline, concentration of MDA, activity of CAT, and SOD was significant at the $1 \%$ probability level (Table 2).

With the irrigation of 75,50 and $25 \%$ of plant water requirement, the chlorophyll a a $(13.2,103.8$ and $170 \%)$, chlorophyll $b(42.8,102.9$ and $163 \%)$, chlorophyll $a+b(23.6,103.4$ and $164.3 \%)$ and carotenoids $(34.8$, 77.6 and 91\%) contents decreased significantly compared to the normal irrigation conditions. The foliar application of $\mathrm{Si}$ at the both levels in summer and spring as well as in summer increased the plant pigments compared to the control (Table 3). Under the well-watered conditions (100\% of plant water requirement), the foliar-applied $\mathrm{Si}$ at the both rates used in summer or spring as well as in summer improved the chlorophyll a ( 43.4 and $44.5 \%)$, chlorophyll $a+b(31.4$ and $28.3 \%)$ contents. Reducing the irrigation water from normal to $75 \%$ of the plant water requirement with the spraying of $S i$ at different concentrations in spring and in summer increased the plant pigments compared to the control (Table 4). With the irrigation of $50 \%$ of plant water requirement, the spraying with different amounts of $S i$ in spring or summer did not affect the carotenoid content, but improved the chlorophyll $a$, chlorophyll $b$, and total chlorophyll contents (Table 5). Potassium silicate spraying at a concentration of $0.4 \%$ in spring, spraying of $S i$ with a concentration of 0.2 and $0.4 \%$ in spring and in summer, and spraying at a concentration of $0.2 \%$ in summer with the irrigation of $25 \%$ of plant water requirement significantly increased the carotenoid content (Table 5).

The irrigation of $50 \%$ and $25 \%$ of plant water requirement increased ion leakage (13.7 and 24.8\%) respectively, as compared with $25 \%$ of plant water requirement, but spraying with $S i$ at different concentrations reduced ion leakage (19.9, 19.9, 13.8, 22, 17.7 and 10.4\%) as compared with control, significantly (Table 3). With the irrigation of $100 \%$ of the plant water requirement, the spraying at the $0.4 \% \mathrm{Si}$ concentration in summer significantly reduced ion leakage. With the irrigation of $75 \%$ of the plant water requirement, the spraying with different concentrations of $\mathrm{Si}$ either in spring or summer or in both spring and summer significantly decreased ion leakage compared to the control (Table 4). With the irrigation of $50 \%$ and $25 \%$ of plant water requirement, the ion leakage rate was significantly reduced by spraying with different amounts of Si except for $0.4 \%$ concentration in summer (Table 5 ).

With irrigation of $50 \%$ and $25 \%$ of plant water requirement, leaf water relative content decreased by $\% 8$ and $\% 14.8$, compared to the control, respectively (Table 3 ). The spraying of $S i$ at the concentrations of 0.2 and $0.4 \%$ either in spring or summer, spraying at the concentrations of 0.2 and $0.4 \%$ in both spring and summer 
increased the leaf water relative content relative to the control by $4.4 \%, 7 \%, 9.8 \%, 12.4 \%, 10.5 \%$ and $15 \%$, respectively (Table 3 ).

Table 2. Analysis of variance for different plant parameters as affected by different experimental treatments

\begin{tabular}{|c|c|c|c|c|c|c|c|c|c|c|c|c|c|}
\hline \multirow[b]{2}{*}{ SOV } & \multirow[b]{2}{*}{ DF } & \multicolumn{11}{|c|}{ Mean Square } & \multirow[b]{2}{*}{$\begin{array}{c}\text { Essence } \\
\text { yield }\end{array}$} \\
\hline & & $\begin{array}{c}\text { Chl a } \\
\text { content }\end{array}$ & $\begin{array}{l}\mathrm{Chl} b \\
\text { content }\end{array}$ & $\begin{array}{c}\text { Chl } \\
a+b \\
\text { content }\end{array}$ & $\begin{array}{c}\text { Carotenoid } \\
\text { content }\end{array}$ & $\begin{array}{l}\text { Electrolyte } \\
\text { leakage }\end{array}$ & $\begin{array}{c}\text { Relative } \\
\text { water } \\
\text { content }\end{array}$ & $\begin{array}{l}\text { Proline } \\
\text { content }\end{array}$ & CAT & SOD & MAD & Flower yield & \\
\hline $\begin{array}{c}\text { Replication } \\
\text { (R) }\end{array}$ & 2 & $0.088^{*}$ & $0.002^{\text {ns }}$ & $0.078^{*}$ & $0.0037^{* *}$ & $13.30^{\text {ns }}$ & $85.58^{* *}$ & $0.22^{\mathrm{ns}}$ & $248.60^{\mathrm{ns}}$ & $20.06^{\text {ns }}$ & $11417.80^{* *}$ & $37272.91^{\text {ns }}$ & $0.052^{*}$ \\
\hline $\begin{array}{l}\text { Irrigation } \\
\text { (I) }\end{array}$ & 3 & $1.59^{\circ}$ & $0.370^{* *}$ & $3.350^{* *}$ & $0.44^{* *}$ & $287.01^{*}$ & $472.91^{* *}$ & $10.12^{* *}$ & $37042.36^{* *}$ & $2.86^{*}$ & $3122.30^{\mathrm{ns}}$ & $503938.01^{*}$ & $0.0038^{\mathrm{ns}}$ \\
\hline $\mathrm{Ea}$ & 6 & 0.02 & 0.003 & 0.019 & 0.0096 & 53.97 & 17.23 & 0.08 & 222.30 & 0.49 & 6241.16 & 52512.96 & 0.018 \\
\hline $\begin{array}{c}\text { Potassium } \\
\text { silicate } \\
\text { (PS) }\end{array}$ & 6 & $0.14 "$ & $0.013^{* *}$ & $0.212^{* *}$ & $0.222^{*}$ & $79.19^{* *}$ & $142.48^{* *}$ & $1.88^{* *}$ & $8363.26^{* *}$ & $8.72^{* *}$ & $13862.20^{* *}$ & $1951456.00^{\mathrm{ns}}$ & $0.011^{\mathrm{ns}}$ \\
\hline $\mathrm{I} \times \mathrm{PS}$ & 18 & $0.017^{\mathrm{ns}}$ & $0.0013^{\text {ns }}$ & $0.007^{\text {ns }}$ & $0.010^{* *}$ & $69.79^{* *}$ & $15.56^{\mathrm{ns}}$ & $1.14^{* *}$ & $2930.44^{* *}$ & $4.78^{* *}$ & $5965.30^{* *}$ & $5622.75^{\mathrm{ns}}$ & $0.002^{\mathrm{ns}}$ \\
\hline $\mathrm{Eb}$ & 48 & 0.023 & 0.003 & 0.013 & 0.0004 & 24.28 & 11.45 & 0.08 & 126.50 & 1.08 & 1531.30 & 62617.20 & 0.016 \\
\hline \multicolumn{2}{|c|}{ CV (\%) } & 24.07 & 17.20 & 12.26 & 4.54 & 13.80 & 4.62 & 8.32 & 7.10 & 29.50 & 10.77 & 12.49 & 0.13 \\
\hline
\end{tabular}

Source of variation (S.O.V), Chlorophyll $a(\mathrm{Chl} a)$, Chlorophyll $b(\mathrm{Chl} b)$, Superoxide dismutase (SOD); Catalase (CAT), Malondialdehyde (MDA)

ns, ${ }^{*}$ and ${ }^{* *}$ : not significant, significant at 5 and $1 \%$ level of probability, respectively.

Table 3. Comparisons of the simple effects of water deficit stress and potassium silicate on the measured traits in Damask rose

\begin{tabular}{|c|c|c|c|c|c|c|c|c|c|c|c|c|}
\hline \multirow{2}{*}{$\begin{array}{c}\begin{array}{c}\text { Experimental } \\
\text { treatment }\end{array} \\
\text { Water deficit } \\
\text { (WD) }\end{array}$} & \multicolumn{11}{|c|}{ Traits } & \multirow[b]{2}{*}{$\begin{array}{c}\text { Essence } \\
\text { yield } \\
(\mathrm{kg} / \mathrm{h})\end{array}$} \\
\hline & $\begin{array}{c}\mathrm{Chl} a \\
\text { content } \\
(\mathrm{mg} / \mathrm{g} \\
\mathrm{fw})\end{array}$ & $\begin{array}{c}\mathrm{Chl} b \\
\text { content } \\
(\mathrm{mg} / \mathrm{g} \\
\mathrm{fw})\end{array}$ & $\begin{array}{c}\text { Chl } \\
a+b \\
\text { content } \\
(\mathrm{mg} / \mathrm{g} \\
\mathrm{fw})\end{array}$ & $\begin{array}{c}\text { Carotenoid } \\
\text { content } \\
(\mathrm{mg} / \mathrm{g} \mathrm{fw})\end{array}$ & $\begin{array}{c}\text { Electrolyte } \\
\text { leakage } \\
(\%)\end{array}$ & $\begin{array}{c}\text { Relative } \\
\text { water } \\
\text { content } \\
(\%)\end{array}$ & $\begin{array}{c}\text { Proline } \\
\text { content } \\
\left(\mu g^{-1}\right. \\
\left.f_{w}\right)\end{array}$ & $\begin{array}{l}\text { CAT } \\
\text { (U.g } \\
\text { fw) }\end{array}$ & $\begin{array}{l}\text { SOD } \\
\text { (U.g } \\
\text { fw) }\end{array}$ & $\begin{array}{c}\text { MAD } \\
\left(\mu \mathrm{mol} \mathrm{g}{ }^{-1}\right. \\
\left.f_{w}\right)\end{array}$ & $\begin{array}{c}\text { Flower } \\
\text { yield } \\
\text { (g/plant) }\end{array}$ & \\
\hline WW & $0.909 \mathrm{a}$ & $0.487 \mathrm{a}$ & $1.396 \mathrm{a}$ & $0.666 a$ & $32.37 \mathrm{~b}$ & $77.28 \mathrm{a}$ & $2.59 \mathrm{~d}$ & $103.96 \mathrm{c}$ & $3.93 \mathrm{a}$ & $346.39 \mathrm{a}$ & $2137.68 \mathrm{a}$ & $0.945 \mathrm{a}$ \\
\hline WD1 & $0.803 a$ & $0.341 \mathrm{~b}$ & $1.129 \mathrm{~b}$ & $0.494 b$ & $33.19 b$ & $76.81 \mathrm{a}$ & $3.42 \mathrm{c}$ & $157.58 \mathrm{~b}$ & $3.22 \mathrm{~b}$ & $366.71 \mathrm{a}$ & $2058.65 a$ & $0.937 \mathrm{a}$ \\
\hline WD2 & $0.446 \mathrm{~b}$ & $0.240 c$ & $0.686 c$ & $0.375 c$ & $36.83 \mathrm{ab}$ & $71.57 \mathrm{bc}$ & $3.64 \mathrm{~b}$ & $206.06 \mathrm{a}$ & $3.18 \mathrm{~b}$ & $375.39 a$ & $2035.75 a$ & $0.967 \mathrm{a}$ \\
\hline WD3 & $0.336 \mathrm{~b}$ & $0.185 \mathrm{~d}$ & $0.528 \mathrm{~d}$ & $0.348 \mathrm{~b}$ & $40.42 \mathrm{a}$ & $67.28 \mathrm{c}$ & $4.27 \mathrm{a}$ & $165.85 \mathrm{~b}$ & $3.7 \mathrm{ab}$ & $364.78 \mathrm{a}$ & $1780.1 \mathrm{~b}$ & $0.941 \mathrm{a}$ \\
\hline \multicolumn{13}{|c|}{ Potassium silicate (PS) } \\
\hline PS1 & $0.457 \mathrm{c}$ & $0.276 \mathrm{~d}$ & $0.733 \mathrm{c}$ & $0.450 \mathrm{c}$ & $40.84 a$ & $67.5 \mathrm{e}$ & $2.76 \mathrm{e}$ & $126.93 \mathrm{~d}$ & $2.68 \mathrm{~b}$ & $428.19 \mathrm{a}$ & $1932.2 \mathrm{a}$ & $0.905^{\mathrm{a}}$ \\
\hline PS2 & $0.530 \mathrm{bc}$ & $0.284 \mathrm{~d}$ & $0.814 \mathrm{bc}$ & $0.420 \mathrm{~d}$ & $34.05 b$ & $70.52 \mathrm{~d}$ & $3.34 \mathrm{~d}$ & $161.78 \mathrm{~b}$ & $4.13 a$ & $364.11 \mathrm{bc}$ & $1938.6 a$ & $0.929 \mathrm{a}$ \\
\hline PS3 & $0.566 \mathrm{bc}$ & $0.295 \mathrm{~cd}$ & $0.860 \mathrm{~b}$ & $0.436 \mathrm{~cd}$ & $34.04 \mathrm{~b}$ & $72.27 \mathrm{~cd}$ & $3.61 b c$ & $163.37 \mathrm{~b}$ & $3.82 \mathrm{a}$ & $376.91 \mathrm{~b}$ & $1997.7 \mathrm{a}$ & $0.962 \mathrm{a}$ \\
\hline PS4 & $0.719 \mathrm{a}$ & $0.362 \mathrm{a}$ & $1.051 \mathrm{a}$ & $0.540 \mathrm{a}$ & $35.86 \mathrm{~b}$ & $74.59 \mathrm{bc}$ & $3.8 \mathrm{ab}$ & $205.82 \mathrm{a}$ & $4.63 a$ & $365.33 b c$ & $2049.9 a$ & $0.958 \mathrm{a}$ \\
\hline PS5 & $0.739 \mathrm{a}$ & $0.344 \mathrm{ab}$ & $1.084 a$ & $0.506 \mathrm{~b}$ & $33.46 \mathrm{~b}$ & $77.75 a$ & $4.01 \mathrm{a}$ & $170.37 \mathrm{~b}$ & $4.08 \mathrm{a}$ & $349.76 \mathrm{bd}$ & $2048.9 a$ & $0.998 \mathrm{a}$ \\
\hline PS6 & $0.655 \mathrm{ab}$ & $0.336 \mathrm{abc}$ & $0.990 \mathrm{a}$ & $0.494 \mathrm{~b}$ & $34.69 \mathrm{~b}$ & $74.16 \mathrm{bc}$ & $3.4 \mathrm{~cd}$ & $147.17 \mathrm{c}$ & $2.44 \mathrm{~b}$ & $314.12 \mathrm{~d}$ & $2001.8 \mathrm{a}$ & $0.937 \mathrm{a}$ \\
\hline PS7 & $0.713 \mathrm{a}$ & $0.302 \mathrm{bcd}$ & $1.013 \mathrm{a}$ & $0.451 \mathrm{c}$ & $36.99 \mathrm{ab}$ & $75.88 \mathrm{ab}$ & $3.46 \mathrm{~cd}$ & $133.15 \mathrm{~d}$ & $2.64 \mathrm{~b}$ & $334.8 \mathrm{~cd}$ & $2007.2 \mathrm{a}$ & $0.942 \mathrm{a}$ \\
\hline
\end{tabular}

Chlorophyll a (Chl a), Chlorophyll $b(\mathrm{Chl} b)$, Superoxide dismutase (SOD); Catalase (CAT), Malondialdehyde (MDA)

Means followed by similar letters in each column are not significantly different at the $5 \%$ level of probability according to Duncan's multiple rang test.

Well-watered (WW), Irrigation equal to75\% PWR (WD1), irrigation equal to 50\% PWR (WD2), irrigation equal to 25\% PWR ( WD3), without spraying of potassium silicate i.e just absolute water application (PS1), spraying of PS with concentration of $\% 0.2$ in spring (PS2), spraying of PS with concentration of $\% 0.4$ in spring (PS3), spraying of PS with concentration of $\% 0.2$ in spring along with summer (PS4), spraying of PS with concentration of $\% 0.4$ in spring along with summer (PS5), spraying of PS with concentration of $\% 0.2$ in summer (PS6) and spraying of PS with concentration of $\% 0.4$ in summer (PS7) 
Table 4. Comparisons of the interaction effects of potassium silicate application under well-watered (100 \% PWR) and irrigation level of 75\% PWR on the measured traits in Damask rose

\begin{tabular}{|c|c|c|c|c|c|c|c|c|c|c|c|c|}
\hline \multirow{2}{*}{$\begin{array}{c}\begin{array}{c}\text { Experimental } \\
\text { treatment }\end{array} \\
\text { Water deficit } \\
\text { (WD). } \\
\text { Potassium } \\
\text { silicate (PS) }\end{array}$} & \multicolumn{11}{|c|}{ Traits } & \multirow[b]{2}{*}{$\begin{array}{c}\text { Essence } \\
\text { yield } \\
(\mathrm{kg} / \mathrm{h})\end{array}$} \\
\hline & $\begin{array}{c}\text { Chl a } \\
\text { content } \\
(\mathrm{mg} / \mathrm{g} \\
\mathrm{fw})\end{array}$ & $\begin{array}{c}\text { Chl b } \\
\text { content } \\
(\mathrm{mg} / \mathrm{g} \mathrm{fw})\end{array}$ & $\begin{array}{c}\mathrm{Chl} \mathrm{a}+\mathrm{b} \\
\text { content } \\
(\mathrm{mg} / \mathrm{g} \mathrm{fw})\end{array}$ & $\begin{array}{c}\text { Carotenoid } \\
\text { content } \\
\text { (mg/g fw) }\end{array}$ & $\begin{array}{l}\text { Electrolyte } \\
\text { leakage (\%) }\end{array}$ & $\begin{array}{c}\text { Relative } \\
\text { water } \\
\text { content } \\
(\%)\end{array}$ & $\begin{array}{l}\text { Proline } \\
\text { content } \\
\left(\mu \mathrm{g} \mathrm{g}^{-1} \mathrm{fw}\right)\end{array}$ & $\begin{array}{l}\text { CAT } \\
\text { (U.g fw) }\end{array}$ & $\begin{array}{l}\text { SOD } \\
\text { (U.g } \\
\text { fw) }\end{array}$ & $\begin{array}{l}\text { MAD } \\
\left(\mu \mathrm{molg}^{-1}\right. \\
\mathrm{fw})\end{array}$ & $\begin{array}{c}\text { Flower } \\
\text { yield } \\
\text { (g/plant) }\end{array}$ & \\
\hline WWPS1 & $\begin{array}{c}0.721 \\
b-e\end{array}$ & $0.473 a$ & $1.194 \mathrm{de}$ & $0.689 \mathrm{~b}$ & $35.13 \mathrm{c}-\mathrm{g}$ & 76.97a-e & $2.32 \mathrm{p}$ & $127.87 \mathrm{jkl}$ & $4.25 \mathrm{c}-\mathrm{h}$ & $390.96 \mathrm{bcd}$ & $2085 \mathrm{ab}$ & $0.916 \mathrm{a}$ \\
\hline WWPS2 & 0782a-e & $0.475 a$ & $1.257 \mathrm{~cd}$ & $0.537 \mathrm{~d}$ & $34.92 \mathrm{c}-\mathrm{g}$ & $75.803 \mathrm{a}-\mathrm{g}$ & $2.42 \mathrm{op}$ & $117.97 \mathrm{klm}$ & $4.54 \mathrm{~b}-\mathrm{f}$ & $385.45 \mathrm{bcd}$ & 2121ab & $0.920 \mathrm{a}$ \\
\hline WWPS3 & $\begin{array}{c}0821 \\
a-d\end{array}$ & $0.471 \mathrm{a}$ & $1.292 \mathrm{bcd}$ & $0.578 \mathrm{c}$ & $34.27 \mathrm{c}-\mathrm{g}$ & $77.103 \mathrm{a}-\mathrm{e}$ & 2.54 nop & $101.64 \mathrm{mno}$ & $5.13 \mathrm{a}-\mathrm{d}$ & $370.97 \mathrm{~b}-\mathrm{e}$ & $2193.9 \mathrm{a}$ & $0.990 \mathrm{a}$ \\
\hline WWPS4 & $1.034 a$ & $0.535 a$ & $1.569 \mathrm{a}$ & $0.688 \mathrm{~b}$ & $34.18 \mathrm{c}-\mathrm{g}$ & $75.2 \mathrm{~b}-\mathrm{g}$ & $2.6 \mathrm{~m}-\mathrm{p}$ & $94.19 \mathrm{no}$ & $2.72 f_{-j}$ & $360.65 b-f$ & $2185 a$ & $0.992 \mathrm{a}$ \\
\hline WWPS5 & $1.042 \mathrm{a}$ & $0.49 \mathrm{a}$ & $1.532 a$ & $0.723 \mathrm{ab}$ & $33.91 \mathrm{c}-\mathrm{g}$ & $79.8 \mathrm{ab}$ & $2.7 \mathrm{l}-\mathrm{p}$ & $94.36 \mathrm{no}$ & $3.79 \mathrm{c}-\mathrm{i}$ & $360.05 b-f$ & 2121ab & $0.983 \mathrm{a}$ \\
\hline WWPS6 & $0.952 \mathrm{ab}$ & $0.498 \mathrm{a}$ & $1.45 \mathrm{abc}$ & $0.714 \mathrm{ab}$ & $32.687 \mathrm{~d}-\mathrm{g}$ & $77.9 \mathrm{a}-\mathrm{d}$ & $2.72 \mathrm{l}-\mathrm{p}$ & $108.681-\mathrm{n}$ & $2.96 \mathrm{e}-\mathrm{j}$ & $299.35 \mathrm{e}-\mathrm{h}$ & $2120.2 \mathrm{ab}$ & $0.930 \mathrm{a}$ \\
\hline WWPS7 & $1.010 \mathrm{a}$ & $0.473 a$ & $1.483 \mathrm{ab}$ & $0.735 a$ & $21.51 \mathrm{~h}$ & $78.2 \mathrm{abc}$ & $2.85 \mathrm{k}-\mathrm{p}$ & 83.03op & $4.16 \mathrm{c}-\mathrm{h}$ & $278.29 \mathrm{~h}$ & $2137 \mathrm{ab}$ & $0.935 \mathrm{a}$ \\
\hline WD1PS1 & $\begin{array}{c}0.551 \\
\mathrm{~d}-\mathrm{i}\end{array}$ & $0.306 \mathrm{~b}-\mathrm{e}$ & $0.857 \mathrm{fg}$ & $0.429 \mathrm{f}$ & $37.89 \mathrm{~b}-\mathrm{g}$ & $71.3 \mathrm{~d}-\mathrm{h}$ & $2.85 \mathrm{k}-\mathrm{p}$ & $136.85 \mathrm{jk}$ & $2.65 f-j$ & $416.32 \mathrm{abc}$ & $2004 \mathrm{ab}$ & $0.893 a$ \\
\hline WD1PS2 & $\begin{array}{c}0.654 \\
\text { c-h } \\
\end{array}$ & $0.319 \mathrm{~b}-\mathrm{d}$ & $0.973 \mathrm{f}$ & $0.427 \mathrm{f}$ & $28.89 \mathrm{fgh}$ & $73.0 \mathrm{c}-\mathrm{g}$ & $2.95 \mathrm{i}-\mathrm{o}$ & $131.747 \mathrm{jk}$ & $4.96 a-e$ & 275.13gh & $2020 \mathrm{ab}$ & $0.909 \mathrm{a}$ \\
\hline WD1PS3 & $\begin{array}{c}0.682 \\
\text { b-g }\end{array}$ & $0.338 \mathrm{bc}$ & $1.02 \mathrm{ef}$ & $0.432 \mathrm{f}$ & $36.68 \mathrm{c}-\mathrm{g}$ & $74.8 \mathrm{~b}-\mathrm{g}$ & $3.36 \mathrm{~g}-\mathrm{k}$ & $142.22 \mathrm{ij}$ & $4.43 \mathrm{~b}-\mathrm{g}$ & $380.74 \mathrm{bcd}$ & 2036ab & $0.938 \mathrm{a}$ \\
\hline WDIPS4 & $1.053 a$ & $0.374 \mathrm{~b}$ & $1.31 \mathrm{bcd}$ & $0.690 \mathrm{~b}$ & $32.69 \mathrm{~d}-\mathrm{g}$ & $79.0 \mathrm{abc}$ & $3.5 \mathrm{e}-\mathrm{i}$ & $215.12 \mathrm{~d}$ & $2.85 f-j$ & $387.42 \mathrm{bcd}$ & 2133.9ab & $0.989 \mathrm{a}$ \\
\hline WDIPS5 & $1.013 \mathrm{a}$ & $0.350 \mathrm{bc}$ & $1.363 \mathrm{a}-\mathrm{d}$ & $0.564 \mathrm{~cd}$ & $28.09 \mathrm{gh}$ & $82.3 a$ & $3.6 \mathrm{~d}-\mathrm{g}$ & $170.48 \mathrm{gh}$ & $2.84 f-j$ & $377.03 \mathrm{bcd}$ & $2067 \mathrm{ab}$ & $0.963 \mathrm{a}$ \\
\hline WDIPS6 & $\begin{array}{c}0.819 \\
\text { a-d } \\
\end{array}$ & $0.364 \mathrm{~b}$ & $1.183 \mathrm{de}$ & $0.485 \mathrm{e}$ & $31.32 \mathrm{e}-\mathrm{g}$ & $78.0 \mathrm{abc}$ & $3.79 \mathrm{~d}-\mathrm{g}$ & $177.48 \mathrm{f}-\mathrm{h}$ & $2.44 \mathrm{~g}-j$ & $367.1 \mathrm{~b}-\mathrm{e}$ & $2086 a b$ & $0.943 \mathrm{a}$ \\
\hline WD1PS7 & $\begin{array}{c}0.855 \\
\mathrm{a}-\mathrm{c} \\
\end{array}$ & $0.342 \mathrm{bc}$ & $1.197 \mathrm{de}$ & $0.434 \mathrm{f}$ & $36.78 \mathrm{c}-\mathrm{g}$ & $79.3 \mathrm{abc}$ & $3.9 \mathrm{~d}-\mathrm{g}$ & $129.2 \mathrm{jk}$ & $2.51 f_{-j}$ & 363.23b-f & 2063.7ab & $0.922 \mathrm{a}$ \\
\hline
\end{tabular}

Chlorophyll $a(\mathrm{Chl} a)$, Chlorophyll $b(\mathrm{Chl} b)$, Superoxide dismutase (SOD); Catalase (CAT), Malondialdehyde (MDA)

Means followed by similar letters in each column are not significantly different at the $5 \%$ level of probability according to Duncan's multiple rang test.

Well-watered (WW), Irrigation equal to 75\% PWR (WD1), irrigation equal to 50\% PWR (WD2), irrigation equal to 25\% PWR ( WD3), without spraying of potassium silicate i.e just absolute water application (PS1), spraying of PS with concentration of $\% 0.2$ in spring (PS2), spraying of PS with concentration of $\% 0.4$ in spring (PS3), spraying of PS with concentration of $\% 0.2$ in spring along with summer (PS4), spraying of PS with concentration of $\% 0.4$ in spring along with summer (PS5), spraying of PS with concentration of \%0.2 in summer (PS6) and spraying of PS with concentration of $\% 0.4$ in summer (PS7)

The amount of leaf proline increased under the water deficit stress and spraying with $\mathrm{Si}$ (Table 3 ). The irrigation of $100 \%$ of plant water requirement did not affect the amount of leaf proline with the spraying of $\mathrm{Si}$. With the irrigation of $75 \%$ and $50 \%$ of plant water requirement, the spraying with concentrations of 0.2 and $0.4 \%$ of $\mathrm{Si}$ in both summer and spring or in summer alone significantly increased the amount of leaf proline (Table 4). The spraying with different concentrations of $\mathrm{Si}$ at different times alone or in combination significantly increased the amount of leaf proline under the irrigation of $25 \%$ of plant water requirement (Table 5).

The leaf catalase activity increased in the water deficit stress and spraying with $\mathrm{Si}$ (Table 3). With the irrigation equal to $100 \%$ of plant water requirement, the leaf catalase activity decreased with the Si spraying. With the irrigation of $75 \%$ of plant water requirement, the spraying with concentrations of 0.2 and $0.4 \%$ of $\mathrm{Si}$ in both summer and spring or the spraying by $0.2 \%$ in summer significantly increased the catalase activity (Table 4). With the irrigation of $50 \%$ of plant water requirement, the spraying at the concentrations of 0.2 and $0.4 \%$ of $\mathrm{Si}$ in spring or in both summer and spring significantly increased the catalase activity. Also, with the irrigation of $25 \%$ of plant water requirement, the spraying with $\mathrm{Si}$ at different concentrations and times alone or in combination increased the leaf catalase activity (Table 5). 
Water deficit stress did not affect the activity of superoxide dismutase, but the spraying with the concentration of 0.2 or $0.4 \%$ of $S i$ in spring and the spraying at the concentration of 0.2 or $0.4 \%$ of $S i$ in both spring and summer significantly increased the activity of superoxide dismutase (Table 3 ). With the irrigation of $100 \%$ of plant water requirement, the spraying of $\mathrm{Si}$ did not affect the activity of superoxide dismutase. The foliar application of $\mathrm{Si}$ with the concentration of 0.2 or $0.4 \%$ in spring increased the activity of superoxide dismutase by 87.2 and $67.2 \%$, as compared to the control, under the irrigation of $75 \%$ of plant water requirement (Table 4). Therefore, with the irrigation of $50 \%$ of plant water requirement, the spraying at the concentrations of 0.2 or $0.4 \%$ of $\mathrm{Si}$ in both spring and summer increased the level of superoxide dismutase 4.9 and 3.3 times, respectively. Also, with the irrigation of $25 \%$ of plant water requirement, the spraying at the concentrations of 0.2 and $0.4 \%$ of $\mathrm{Si}$ in spring and also in summer increased the activity of superoxide dismutase by $63.8 \%$ and $97.8 \%$ compared to the control, respectively (Table 5 ).

Table 5. Comparisons of the interaction effects of potassium silicate application under irrigation level of 50 and 25\% PWR on the measured traits in Damask rose

\begin{tabular}{|c|c|c|c|c|c|c|c|c|c|c|c|c|}
\hline \multirow{2}{*}{$\begin{array}{c}\begin{array}{c}\text { Experimental } \\
\text { treatment }\end{array} \\
\text { Water deficit } \\
\text { (WD) } \times \\
\text { Potassium } \\
\text { silicate (PS). }\end{array}$} & \multicolumn{11}{|c|}{ Traits } & \multirow[b]{2}{*}{$\begin{array}{c}\text { Essence } \\
\text { yield } \\
(\mathrm{kg} / \mathrm{h})\end{array}$} \\
\hline & $\begin{array}{c}\mathrm{Chl} \mathrm{a} \\
\text { content } \\
(\mathrm{mg} / \mathrm{g} \\
\mathrm{fw})\end{array}$ & $\begin{array}{c}\mathrm{Chl} \mathrm{b} \\
\text { content } \\
(\mathrm{mg} / \mathrm{g} \\
\mathrm{fw}) \\
\end{array}$ & $\begin{array}{c}\mathrm{Chl} \mathrm{a}+\mathrm{b} \\
\text { content } \\
(\mathrm{mg} / \mathrm{g} \\
\mathrm{fw}) \\
\end{array}$ & $\begin{array}{c}\text { Carotenoid } \\
\text { content } \\
(\mathrm{mg} / \mathrm{g} \mathrm{fw})\end{array}$ & $\begin{array}{l}\text { Electrolyte } \\
\text { leakage } \\
(\%)\end{array}$ & $\begin{array}{c}\text { Relative water } \\
\text { content }(\%)\end{array}$ & $\begin{array}{c}\text { Proline } \\
\text { content } \\
\left(\mu g^{-1}\right. \\
f w) \\
\end{array}$ & $\begin{array}{c}\text { CAT } \\
(\mathrm{U} . \mathrm{g} \mathrm{fw})\end{array}$ & $\begin{array}{l}\text { SOD } \\
\text { (U.g fw) }\end{array}$ & $\begin{array}{l}\text { MAD } \\
\left(\mu \mathrm{mol} \mathrm{g}^{-1}\right. \\
\mathrm{fw})\end{array}$ & $\begin{array}{c}\text { Flower } \\
\text { yield } \\
\text { (g/plant) }\end{array}$ & \\
\hline WD2PS1 & $0.370 h-j$ & $0.175 \mathrm{gh}$ & $0.547 \mathrm{ij}$ & 0.371 ghi & $40.15 \mathrm{~b}-\mathrm{e}$ & $65.33 \mathrm{hi}$ & $2.900 \mathrm{j}-\mathrm{o}$ & $170.52 \mathrm{gh}$ & $1.343 j$ & 436.13ab & $1961 \mathrm{ab}$ & $0.932 \mathrm{a}$ \\
\hline WD2PS2 & $0.409 \mathrm{~g}-\mathrm{j}$ & $0.186 \mathrm{gh}$ & $0.585 \mathrm{ij}$ & $0.379 \mathrm{gh}$ & $37 / 04 \mathrm{c}-\mathrm{g}$ & $69.20 \mathrm{~g}-\mathrm{i}$ & $3.230 \mathrm{~h}-1$ & $209.95 \mathrm{de}$ & $2.83 \mathrm{f}-\mathrm{j}$ & $372.9 \mathrm{~b}-\mathrm{e}$ & $2089 \mathrm{ab}$ & $0.993 \mathrm{a}$ \\
\hline WD2PS3 & $0.433 \mathrm{~g}-\mathrm{j}$ & $0.215 \mathrm{e}-\mathrm{h}$ & $0.647 \mathrm{~g}-\mathrm{j}$ & $0.384 \mathrm{gh}$ & $30.89 \mathrm{efg}$ & 71.00e-h & $3.430 \mathrm{f}-\mathrm{j}^{-}$ & $236.88 \mathrm{bc}$ & $2.51 f_{-j}$ & $327.42 \mathrm{~d}-\mathrm{g}$ & $1969 \mathrm{ab}$ & $0.974 \mathrm{a}$ \\
\hline WD2PS4 & $0.468 f_{-j}$ & $0.283 \mathrm{~b}-\mathrm{f}$ & 0.75 lghi & $0.395 \mathrm{fg}$ & $35.71 \mathrm{c}-\mathrm{g}$ & $73.72 \mathrm{~b}-\mathrm{g}$ & $3.840 \mathrm{~d}-\mathrm{g}$ & $267.01 \mathrm{a}$ & $6.54 a$ & $380 \mathrm{~b}-\mathrm{d}$ & $2074 \mathrm{ab}$ & $0.953 \mathrm{a}$ \\
\hline WD2PS5 & $0.492 \mathrm{f}-\mathrm{i}$ & $0.325 \mathrm{bc}$ & $0.817 \mathrm{fgh}$ & $0.382 \mathrm{gh}$ & $33.3 \mathrm{c}-\mathrm{g}$ & $76.00 \mathrm{a}-\mathrm{f}$ & $4.120 \mathrm{~d}$ & $223.36 \mathrm{dc}$ & $4.43 \mathrm{~b}-\mathrm{g}$ & $370.97 \mathrm{~b}-\mathrm{e}$ & $2067 \mathrm{ab}$ & $1.014 \mathrm{a}$ \\
\hline WD2PS6 & $0.431 \mathrm{~g}-\mathrm{j}$ & $0.274 \mathrm{~b}-\mathrm{g}$ & $0.705 \mathrm{~g}-\mathrm{i}$ & $0.38 \mathrm{gh}$ & $33.75 \mathrm{c}-\mathrm{g}$ & $71.03 \mathrm{e}-\mathrm{h}$ & $3.960 \mathrm{~d}-\mathrm{f}$ & $159.33 \mathrm{hi}$ & $2.44 \mathrm{~g}-\mathrm{j}$ & $347.74 \mathrm{c}-\mathrm{g}$ & $2010 \mathrm{ab}$ & $0.936 \mathrm{a}$ \\
\hline WD2PS7 & $0.532 \mathrm{e}-\mathrm{i}$ & $0.222 \mathrm{e}-\mathrm{h}$ & $0.751 \mathrm{~g}-\mathrm{i}$ & $0.335 \mathrm{ij}$ & $46.99 \mathrm{ab}$ & $74.7 \mathrm{~b}-\mathrm{g}$ & $4.030 \mathrm{de}$ & $175.43 \mathrm{fgh}$ & $2.19 \mathrm{~h}-\mathrm{j}$ & $382.58 \mathrm{~b}-\mathrm{d}$ & $2032 \mathrm{ab}$ & $0.966 \mathrm{a}$ \\
\hline WD3PS1 & $0.184 \mathrm{j}$ & $0.150 \mathrm{~h}$ & $0.334 \mathrm{k}$ & $0.312 j$ & $50.2 \mathrm{a}$ & $56.4 \mathrm{j}$ & $2.990 \mathrm{i}-\mathrm{n}$ & $72.47 \mathrm{p}$ & $3.21 \mathrm{~d}-\mathrm{j}$ & $469.25 a$ & $1678.6 \mathrm{ab}$ & $0.894 \mathrm{a}$ \\
\hline WD3PS2 & $0.284 \mathrm{ij}$ & $0.156 \mathrm{~h}$ & $0.44 \mathrm{jk}$ & $0.338 \mathrm{ij}$ & $35.36 \mathrm{c}-\mathrm{g}$ & $64.067 \mathrm{i}$ & $4.750 \mathrm{c}$ & $187.46 \mathrm{fg}$ & $4.18 \mathrm{c}-\mathrm{h}$ & $422.96 \mathrm{abc}$ & $1704 a b$ & $0.946 \mathrm{a}$ \\
\hline WD3PS3 & $0.329 \mathrm{ij}$ & $0.156 \mathrm{~h}$ & $0.482 \mathrm{jk}$ & $0.352 \mathrm{hi}$ & $34.32 \mathrm{c}-\mathrm{g}$ & $66.167 \mathrm{hi}$ & $5.100 \mathrm{bc}$ & $172.73 \mathrm{gh}$ & $3.21 \mathrm{~d}-\mathrm{j}$ & $418.49 \mathrm{abc}$ & $1762 \mathrm{ab}$ & $0.947 \mathrm{a}$ \\
\hline WD3PS4 & $0.32 \mathrm{ij}$ & $0.254 \mathrm{c}-\mathrm{h}$ & $0.574 \mathrm{ij}$ & $0.385 \mathrm{gh}$ & $40.84 \mathrm{bcd}$ & $70.433 \mathrm{c}-\mathrm{g}$ & $5.260 \mathrm{ab}$ & $246.94 \mathrm{~b}$ & $6.35 \mathrm{ab}$ & $333.26 \mathrm{~d}-\mathrm{f}$ & $1806 \mathrm{ab}$ & $1.033 \mathrm{a}$ \\
\hline WD3PS5 & $0.367 \mathrm{~h}-\mathrm{j}$ & $0.210 \mathrm{e}-\mathrm{h}$ & $0.624 \mathrm{~h}-j$ & $0.356 \mathrm{ghi}$ & $38.55 \mathrm{~b}-\mathrm{f}$ & $72.9 \mathrm{c}-\mathrm{g}$ & $5.630 \mathrm{a}$ & $193.260 \mathrm{ef}$ & $5.26 \mathrm{abc}$ & $290.97 \mathrm{fgh}$ & 1923.1ab & $0.939 \mathrm{a}$ \\
\hline WD3PS6 & $0.417 \mathrm{~g}-\mathrm{j}$ & $0.206 \mathrm{e}-\mathrm{h}$ & $0.623 \mathrm{~h}-j$ & $0.395 \mathrm{fg}$ & $41.03 \mathrm{bcd}$ & $69.7 \mathrm{f}-\mathrm{i}$ & $\begin{array}{c}3.120 \mathrm{~h}- \\
\mathrm{m}\end{array}$ & $143.180 \mathrm{ij}$ & $2.04 \mathrm{ij}$ & 283.31gh & 1791ab & $0.945 \mathrm{a}$ \\
\hline WD3PS7 & $0.454 \mathrm{f}-\mathrm{j}$ & $0.169 \mathrm{~h}$ & $0.623 \mathrm{~h}-\mathrm{j}$ & $0.300 \mathrm{j}$ & $42.68 \mathrm{abc}$ & $71.3 \mathrm{~d}-\mathrm{h}$ & $3.060 \mathrm{~h}-\mathrm{n}$ & $144.940 \mathrm{ij}$ & $1.68 \mathrm{j}$ & $336.11 \mathrm{~d}-\mathrm{g}$ & $1796 a b$ & $0.922 \mathrm{a}$ \\
\hline
\end{tabular}

Chlorophyll a (Chl a), Chlorophyll b (Chl b), Superoxide dismutase (SOD); Catalase (CAT), Malondialdehyde (MDA)

Means followed by similar letters in each column are not significantly different at the $5 \%$ level of probability according to Duncan's multiple rang test.

Well-watered (WW), Irrigation equal to75\% PWR (WD1), irrigation equal to 50\% PWR (WD2), irrigation equal to $25 \%$ PWR ( WD3), without spraying of potassium silicate i.e just absolute water application (PS1), spraying of PS with concentration of \%0.2 in spring (PS2), spraying of PS with concentration of \% 0.4 in spring (PS3), spraying of PS with concentration of \% 0.2 in spring along with summer (PS4), spraying of PS with concentration of $\% 0.4$ in spring along with summer (PS5), spraying of PS with concentration of $\% 0.2$ in summer (PS6) and spraying of PS with concentration of $\% 0.4$ in summer (PS7)

The concentration of malondialdehyde significantly decreased with the spraying of $\mathrm{Si}$ in different concentrations and seasons (Table 3 ). With the irrigation of $100 \%$ of plant water requirement and the spraying of $\mathrm{Si}$ at the concentration of 0.2 or $0.4 \%$ in summer, the malondialdehyde content decreased by $30.6 \%$ and $40.4 \%$ compared to the control, respectively. With the irrigation of $75 \%$ of plant water requirement, the spraying of $\mathrm{Si}$ at the concentrations of 0.2 and $0.4 \%$ in spring or summer or in combination decreased the level of malondialdehyde compared to the control (Table 4). With the irrigation of $50 \%$ of plant water requirement and the spraying of $S i$ at the concentrations of $0.4 \%$ in spring and at the concentration of $0.2 \%$ in summer, the 
level of malondialdehyde decreased significantly compared to the control. Also, with the irrigation of $25 \%$ of plant water requirement and the spraying of $S i$ at the concentrations of 0.2 and $0.4 \%$ in both spring and summer or in summer, the level of malondialdehyde significantly decreased compared to the control (Table 5).

The irrigation of 75 and $50 \%$ of plant water requirement compared to the irrigation of $100 \%$ of plant water requirement did not have a significant difference in flower yield, but with the irrigation of $25 \%$ of plant water requirement, the flower yield decreased by $20 \%$ compared to the control (Table 3 ). With the irrigation of $50 \%$ of plant water requirement together with the spraying of $\mathrm{Si}$ at the concentration of 0.2 or $0.4 \%$ in summer, the optimal flower yield can be achieved (Table 4).

The main effects of water stress and $S i$ and their interaction effect on the essential yield was insignificant (Tables 2 and 3) but in each level of water stress, foliar spray of Si resulted in increase in the essential yield as compared with the control (Tables 4 and 5).

\section{Discussion}

The reduced chlorophyll content due to the water stress is associated with the increase in the production of oxygen radicals in cells, where the radicals cause the peroxidation and, as a result, decomposition of photosynthetic pigments (Sheteawi and Tawfik, 2007). The effect of potassium silicate on the stability of plant pigments can be attributed to the accumulation of silicate in epidermal cells, which has an indirect protective effect on the photosynthetic device and therefore, reduces the damage induced by the stress to the photosynthetic pigments (Klyngerda Silva et al., 2013). Similar to our result, moderator effect of Si on biomass and chlorophyll content of corn plants subjected to the drought stress has been reported (Kaya et al., 2006). Silicate reduces the damage to the carotenoids. The increased level of carotenoids with the use of silicate under the drought stress conditions has been reported in oxtongue (Torabi et al., 2013).

Silicon $(\mathrm{Si})$ plays an important role in the plant defense capacity under the environmental stress. Within the plant, silicate is a non-mobile element, which becomes a polymer gel and reduces ion leakage from the biomembranes after being deposited inside the cell (Liang et al., 2007). The results of this study are consistent with the findings of Zhu et al. (2004) who stated that the increased stability of the cell membrane in the presence of silicon is due to the wall hardening and firmness. The reduced water loss in the plants supplied with $\mathrm{Si}$ may also be due to the lower transpiration from the plants. The accumulation of silicate in the lower epidermal cells reduces the water loss through the cuticle (Hattori et al., 2008).

The results showed that the leaf proline concentration significantly increased with the water deficit and foliar-applied Si. Si may directly or indirectly induce proline biosynthesis (Liang et al., 2006). The treatment of borage (Borago officinalis L.) with silica has been reported to increase the amount of leaf proline (Gagoonani et al., 2011). In line with these results, Pereira et al. (2013) reported that the effect of silica application increased the proline content in pepper plants subjected to the drought stress.

An increase in the leaf CAT activity was observed under the both water deficit stress and foliar-applied $\mathrm{Si}$. The elevated activity of CAT in plants is an adaptive mechanism, preventing cells from oxidative damage by reducing the hydrogen peroxide concentration produced from the cellular metabolism (Gill and Tuteja, 2010). By stimulating the activity of CAT through the detoxification of hydrogen peroxide, Si prevents the oxidative stress and inhibits the hydroxyl radical production (Rastgoo and Alemzadeh, 2011). Aligned with our results, Gong et al. (2005) reported that the use of silica increased catalase and superoxide dismutase in wheat grown under the drought stress.

Superoxide dismutase is an enzyme that catalyzes the free radicals of superoxide into hydrogen peroxide and oxygen and plays an important role in protecting the cells against the adverse effects of the radicals (Linag et al., 2007). SOD is the first cell defense line against the attack of free radicals under the stress conditions (Tale Ahmad and Haddad, 2011). In this study, under the water stress conditions (application of irrigation water by 50 and $25 \%$ of the plant water requirement), the foliar-applied Si at the both rates of 0.2 and $0.4 \%$ in summer 
led to the increased activity of SOD. The effect of Si nutrition on SOD activity and removed free radicals has been reported (Gong et al., 2005). Taheri and Haghighi (2018) reported that the application of potassium silicate at $5 \mathrm{mM}$ concentration increased the activity of antioxidant enzymes in pepper under the thermal stress conditions $\left(35^{\circ} \mathrm{C}\right)$.

Malondialdehyde is the peroxidation product of unsaturated fatty acids in phospholipids. Therefore, the production of malondialdehyde under the stress conditions is used as a marker to indicate the lipid peroxidation (Katsuhara et al., 2005). Due to the dryness, the peroxidation of the glycopeptides of chloroplast thylakoid occurred followed by the production of diacylglycerol, triacylglycerol and free fatty acids, resulting in a higher level of malondialdehyde in the plant tissues (Smirnoff, 1993). Fatty acids and lipids are reported to be highly susceptible to oxygen species and are rapidly oxidized. Si removing the reactive oxygen species decreases the permeability of the cell membrane and increases the activity of catalase, peroxidase and superoxide dismutase, which indirectly reduces the peroxidation of cell membrane lipids and lowers the amount of malondialdehyde (Liang et al., 2007). The results of this study are consistent with other findings indicating the positive effect of Si on the yield of corn (Kaya et al., 2006) and barley (Liang et al., 2003). By decreasing the vegetative growth and changing the anatomical structure of plant through the induction of secondary stresses such as oxidative stress, drought stress causes the changes in the synthesis pathways of secondary compounds and metabolites (Foyer et al., 2012).

\section{Conclusions}

The results showed that under the water deficit stress conditions, the catalase activity, proline, and ion leakage increased and the leaf water relative content, plant pigments, and yield decreased in the Damask rose flower. The spraying with potassium silicate at the concentration of 0.2 or $0.4 \%$ in spring or summer alone or in combination increased the leaf water relative content, content of plant pigments, activity of catalase and superoxide dismutase, proline content, and flower yield and decreased the rate of ion leakage and malondialdehyde content. In general, the results showed that for the irrigation equal to $50 \%$ of the plant water

requirement along with the potassium silicate spraying at the 0.2 or $0.4 \%$ level both in spring and summer, by improving the activity of the antioxidants and reducing the damage caused by the water stress conditions, the flower Damask rose optimum yield is achieved.

\section{Authors' Contributions}

All authors read and approved the final manuscript.

\section{Acknowledgements}

The authors gratefully acknowledge the research department of Islamic Azad University of Arak branch and Karimah Zaer Institute of Qom, Iran for supporting the current research.

\section{Conflict of Interests}

The authors declare that there are no conflicts of interest related to this article. 
Farahani H et al. (2020). Not Bot Horti Agrobo 48(3):1560-1572

\section{References}

Ahmad P, Prasad MNV (2012). Abiotic stress responses in plants. Metabolism, Productivity and Sustainability. New York. Springer.

Amin M, Ahmad R, Ali A, Aslam M, Lee DJ (2015). Silicon fertilization improves the maize (Zea mays L.) performance under limited moisture supply. Cereals Research Communications 44:172-185. https://doi.org/10.1556\%2F0806.43.2015.035

Aravind P, Prasad MNV (2005). Cadmium induced toxicity reversal by zinc in Ceratophyllum demersum L. (a free floating aquatic macrophyte) together with exogenous supplements of amino- and organic acids. Chemosphere 61:1720-1733. https://doi.org/10.1016/j.chemosphere.2005.03.088

Arnon DI (1994). Copper enzymes in isolated chloroplasts, polyphenoloxidase in Beta vulgaris. Plant Physiology 24:1-15. https://doi.org/10.1104/pp.24.1.1

Barzegari F, Malekinezhad H (2016). Estimating irrigation requirements under climate change (Case Study: YazdArdakan Plain). Journal of Irrigation Sciences and Engineering 39(4):85-95. [In Persian].

Bates LS, Waldren RP, Teare LD (1973). Rapid determination of free proline for water-stress studies. Plant Soil 39:205207. https://doi.org/10.1007/BF00018060

Baxter A, Mittler R, Suzuki N (2014). ROS as key players in plant stress signaling. Journal of Experimental Botany 65(5):1229-1240. https://doi.org/10.1093/jxb/ert375

Baydar H, Baydar NG (2004). The effects of harvest date, fermentation duration and tween 20 treatment on essential oil content and composition of industrial oil rose (Rose damascena Mill.). Industrial Crops and Product 21(2):251255.

Bidabadi M, Behbahani MR, Farshi AA (2013). CROPWAT. Learning of software (for Windows). Crop water requirements and irrigation scheduling. University Jahad Press, pp 136. [In Persian].

da Silva Lobato AK, Silva Guedes EM, Marques JD, de Oliveira Neto CF (2013). Silicon: A benefic element to improve tolerance in plants exposed to water deficiency. In: Akinci (Eds). Responses of organisms to water stress. Publisher In. Tech. pp 95-113. http://dx.doi.org/10.5772/53765

Dhopte AM, Manuel LM (2002). Principals and techniques for plant scientists. Lst End. Updesh purohit for Agrobios (India) Odupur, pp 373.

Foyer CH, Lelandais M, Kunert KJ (1994). Photooxidative stress in plants. Physiologia Plantarum 92:696-717. https://doi.org/10.1111/j.1399-3054.1994.tb03042.x

Gagoonani S, Enteshari S, Delavar K, Behyar M (2011). Interactive effects of silicon and aluminum on the malondialdehyde (MDA), proline, protein and phenolic compounds in Borago officinalis L. Journal of Medicinal Plants Research 5(24):5818-5827. https://doi.org/10.5897/JMPR.9000818

Gengmao Z, Shihui L, Xing S, Yizhou W, Zipan Ch (2015). The role of silicon in physiology of the medicinal plant (Lonicera japonica L.) under salt stress. Scientific Reports 5:12696. https://doi.org/10.1038/srep12696

Giannopolitis CN, Ries SK (1977). Superoxide dismutases. Plant Physiology 59:309-314. https://doi.org/10.1104/pp.59.2.309

Gill SS, Tuteja N (2010). Reactive oxygen species and antioxidant machinery in abiotic stress tolerance in crop plants. Plant Physiology and Biochemistry 48:909-930. https://doi.org/10.1016/j.plaphy.2010.08.016

Gong HJ, Chen KM, Chen G, Wang S, Zhang CL (2005). Effects of silicon on growth of wheat under drought. $13^{\text {th }}$ International Soil Conservation Organization Conference-Brisbane, July pp 10-11.

González-Orenga S, Boscaiu M, Plazas M, Sestras AF, Prohens J, Vicente O, Sestras RE (2020). Responses to water deficit and salt stress in silver fir (Abies alba Mill.) seedlings. Forests 11(4):395. https://doi.org/10.3390/f11040395

Hattori T, Sonobe K, Inanaga S, An P, Morita S (2008). Effects of silicon on photosynthesis of young cucumber seedlings under osmotic stress. Journal of Plant Nutrition 31(6):1046-1058. https://doi.org/10.1080/01904160801928380

Hasanuzzaman M, Nahar K, Gill SS, Fujita M (2014). Drought stress responses in plants, oxidative stress, and antioxidant defense. Climate Change and Plant Abiotic Stress Tolerance 18:209-250. https://doi.org/10.1002/9783527675265.ch09

Katsuhara M, Otsuka T, Ezaki B (2005). Salt stress-induced lipid peroxidation is reduced by glutathione S-transferase, but this reduction of lipid peroxides is not enough for a recovery of root growth in Arabidopsis. Plant Sciences 169(2):369-373. https://doi.org/10.1016/j.plantsci.2005.03.030 
Kaya C, Tuna L, Higgs D (2006). Effect of silicon on plant growth and mineral nutrition of maize grown, under water stress condition. Journal of Plant Nutrition 29:1469-1480. https://doi.org/10.1080/01904160600837238

Kim YH, Khan AL, Waqas M, Lee1 IJ (2017). Silicon regulates antioxidant activities of crop plants under abiotic-induced oxidative stress: a review. Frontiers in Plant Science 8:1-7. https://doi.org/10.3389/fpls.2017.00510

Kodori MR, Tabaei-Aghdaei SR (2007). Evaluation of flower yield and yield components in nine Rosa damascena miller accessions of Kerman province. Iranian Journal of Medicinal and Aromatic Plants Research 25(1):100-110.

LiangY, Sun W, Zhu Y, Christie P (2007). Mechanisms of silicon-mediated alleviation of abiotic stresses in higher plantsa review. Environmental Pollution 147:422-428. https://doi.org/10.1016/j.envpol.2006.06.008

Liang YC, Chen Q, Liu Q, Zhang WH, Ding RX (2003). Exogenous silicon increases antioxidant enzyme activity and reduces lipid peroxidation in roots of salt-stressed barley (Hordeum vulgare L.). Journal of Plant Physiology 160:1157-1164. https://doi.org/10.1078/0176-1617-01065

Liang Y, Hua H, Zhu YG, Zhang J, Cheng C, Romheld V (2006). Importance of plant species and external silicon concentration to active silicon uptake and transport. New Phytologist 172(1):63-72. https://doi.org/10.1111/j.1469-8137.2006.01797.x

Lutts S, Kinet JM, Bouharmont J (1996). NaCl-Induced senescence in leaves rice (Oryza sativa L.) Cultivars differing in salinity resistance. Annals of Botany 78(3):389-398. https://doi.org/10.1006/anbo.1996.0134

Pereira TS, Lobato AKS, Tan DKY, Costa DV, Uchoa EB, Ferreira RN, ... Guedes EMS (2013). Positive interference of silicon on water relations nitrogen metabolism, and osmotic adjustment in two pepper (Capsicum annuum) cultivars under water deficit. Australian Journal of Crop Science 126(6):775-786.

Rastgoo L, Alemzadeh A (2011). Biochemical responses of gouan (Aeluropus littoralis) to heavy metals stress. Australian Journal of Crop Science 5(4):375-383.

Reza MM, Ullah S, Aziz T, Abbas T, Yousaf MM, Altay V, Ozturk M (2019). Alleviation of salinity stress in maize using silicon nutrition. Notulae Botanicae Horti Agrobotanici Cluj-Napoca 47(4):340-1347. https://doi.org/10.15835/nbha47411584

Sajedi N, Madani H, Naderi A (2011). Effect of microelements and selenium on superoxide dismutase enzyme, malondialdehyde activity and grain yield maize (Zea mays L.) under water deficit stress. Notulae Botanicae Horti Agrobotanici Cluj-Napoca 39(2):153-159. https://doi.org/10.15835/nbha3925500

Sharifi AE, Rouhipour H, Assareh MH, Tabei ASR, Lebaschy MH, Naderi B (2015). Determination of water requirement of Rosa damascene Mill. using lysimeter. Iranian Journal of Medicinal and Aromatic Plants 30(6):923-931.

Sheteawi SA, Tawfik KM (2007). Interaction effect of some biofertilizers and irrigation water regime on mungbean (Vigna radiate) growth and yield. Journal of Applied Sciences Research 3(3):251-262.

Siminis C, Kanellis AK, Roubelakis-Angelakis KA (1994). Catalase is differentially expressed in dividing and nondividing protoplasts. Plant Physiology105:1375-1383. https://doi.org/10.1104/pp.105.4.1375

Smirnoff N (1993). The role of active oxygen in response of plants to water deficit and desiccation. New Phytologist 125:27-58. https://doi.org/10.1111/j.1469-8137.1993.tb03863.x

Taheri M, Haghighi M (2018). Benzyl adenine is more effective than potassium silicate on decreasing the detrimental effects of heat stress in pepper (Capsicum annum cv. PS301). Iran Agricultural Research 37(1):89-98. https://doi.org/10.22099/IAR.2018.4890

Tale AS, Haddad R (2011). Study of silicon effects on antioxidant enzyme activities and osmotic adjustment of wheat under drought stress. Czech Journal of Genetics and Plant Breeding 47(1):17-27. https://doi.org/10.17221/92/2010-CJGPB

Torabi F, Majd A, Enteshari SH, Ayrean S (2013). Study of effect of silicon on some anatomical and physiological characteristics of borage (Borago officinalis L.) in hydroponic conditions. Journal of Cell and Tissue 4(3):275-285.

Tripathi DK, Singh S, Singh VP, Prasad SM, Dubey NK, Chauhan DK (2017). Silicon nanoparticles more effectively alleviated UV-B stress than silicon in wheat (Triticum aestivum) seedlings. Plant Physiology and Biochemistry 110:70-81. https://doi.org/10.1016/j.plaphy.2016.06.026

Zhu Z, Wei G, Li J, Qian Q, Yu J (2004). Silicon alleviates salt stress and increase antioxidant enzymes activity in leaves of Salt-stressed Cucumber. Journal of Plant Science 167:527-533. https://doi.org/10.1016/j.plantsci.2004.04.020 
Farahani H et al. (2020). Not Bot Horti Agrobo 48(3):1560-1572

OPEN ACCESS

(c) (2)

The journal offers free, immediate, and unrestricted access to peer-reviewed research and scholarly work. Users are allowed to read, download, copy, distribute, print, search, or link to the full texts of the articles, or use them for any other lawful purpose, without asking prior permission from the publisher or the author.

License - Articles published in Notulae Botanicae Horti Agrobotanici Cluj-Napoca are Open-Access, distributed under the terms and conditions of the Creative Commons Attribution (CC BY 4.0) License. (C) Articles by the authors; UASVM, Cluj-Napoca, Romania. The journal allows the author(s) to hold the copyright/to retain publishing rights without restriction. 